\title{
O CONSELHO ADMINISTRATIVO DE DEFESA ECONÔMICA - CADE E O CONTRATO ADMINISTRATIVO
}

\author{
MAURO ROBERTO GOMES DE MATTOS
}

1. Considerações iniciais - II. Das infrações da ordem econômica julgadas pelo CADE - III. O CADE e o contrato administrativo - IV. Reflexões finais.

\section{Considerações iniciais}

O Conselho Administrativo de Defesa Econômica - CADE, foi transformado em Autarquia, pela Lei de $n^{\circ} 8.884$, de 11 de junho de 1994, com a finalidade de dispor sobre a prevenção e a repressão às infrações contra a ordem econômica, orientada pelos ditames constitucionais de liberdade de iniciativa, livre concorrência, função social da propriedade, defesa dos consumidores e repressão ao abuso de poder econômico. ${ }^{1}$

$E$ logo no parágrafo único do seu artigo inaugural, a Lei $n^{\circ} 8.884 / 94$, deixou consignado, que:

"A coletividade é a titular dos bens jurídicos protegidos por esta lei."

Pois bem, o CADE vem desenvolvendo a sua atuação para a formação da cultura da concorrência livre e sadia, com repressão aos abusos do poder econômico.

A Lei $n^{\circ} 8.884 / 94$ ao transformar o CADE em Autarquia Federal, vinculou-a ao Ministério da Justiça, com sede e foro no Distrito Federal. ${ }^{2}$

Tendo como composição um presidente e 6 conselheiros, que são escolhidos dentre cidadãos com mais de trinta anos de idade, de notório saber jurídico ou econômico e reputação ilibada, nomeados pelo Presidente da República, depois de aprovados pelo Senado Federal, ${ }^{3}$ com mandato de 2 anos, permitida uma recondução. ${ }^{4}$

1 Cf. $o$ art. $1^{\circ}$ da Lei $n^{\circ} 8.884 / 94$.

2 Art. $3^{\circ}$ da Lei $n^{\circ} 8.884 / 94$.

3 Art. $4^{\circ}$ da Lei $n^{\circ} 8.884 / 94$.

$4 \S 1^{\circ}$ do art. $4^{\circ}$ da Lei $n^{\circ} 8.884 / 94$.

R. Dir. Adm.,

Rio de Janeiro, 224: 301-322, abr./jun. 2001 
Consoante dicção do art. $7^{\circ}$, compete ao Plenário do CADE:

a) zelar pela observância da Lei $n^{\circ} 8.884 / 94$ e do Regimento Interno do Conselho;

b) decidir sobre a existência de infração à ordem econômica e aplicar as penalidades previstas em lei;

c) decidir os processos instaurados pela Secretaria de Direito Econômico do Ministério da Justiça - SED;

d) decidir os recursos de ofício do Secretário do SED;

$e$ ) ordenar providências que conduzam à cessação de infrações à ordem econômica;

f) aprovar os termos do compromisso de cessação de prática e do compromisso de desempenho, bem como determinar à SDE que fiscalize o seu cumprimento;

g) apreciar em grau de recurso as medidas preventivas adotadas pela SDE ou pelo Conselheiro-Relator;

h) intimar os interessados de suas decisões;

i) requisitar informações de quaisquer pessoas, órgãos, autoridades e entidades públicas ou privadas, bem como determinar as diligências que se fizerem necessários ao exercício das suas funções;

j) requisitar dos Órgãos do Poder Executivo Federal e solicitar das autoridades dos Estados, Municípios, Distrito Federal e territórios as medidas necessárias ao cumprimento desta lei;

k) contratação de profissionais para a realização de exames, vistorias e estudos, pagos pela empresa que vier a ser punida;

l) apreciar os atos ou condutas, sob qualquer forma manifestados, sujeitos à aprovação nos termos do art. 54, fixando compromisso de desempenho, quando for o caso;

$m$ ) requerer ao Poder Judiciário a execução de suas decisões; Federal;

n) requisitar serviços e pessoal de quaisquer órgãos e entidades do Poder Público

o) determinar à Procuradoria do $\mathrm{CADE}$ a adoção de providências administrativas e judiciais;

p) firmar contratos e convênios com órgãos ou entidades nacionais e submeter, previamente, ao Ministro de Estado da Justiça os que devam ser celebrados com organismo estrangeiro ou internacionais;

q) responder a consultas sobre matéria de sua competência;

r) instruir o público sobre as formas de infração da ordem econômica;

s) elaboração e aprovação do seu regimento interno;

t) propor a estrutura do quadro de pessoal da autarquia, observando o disposto no inciso II, do artigo $37 \mathrm{da} C F$;

u) elaborar proposta orçamentária;

v) indicar o substituto eventual do Procurador-geral, nos casos de faltas, afastamento ou impedimentos.

Visando dar maior eficiência ao combate de condutas anticoncorrênciais, zelando pelo funcionamento eficiente do mercado, o CADE conta com a importante ajuda da Secretaria de Direito Econômico do Ministério da Justiça - SDE, dirigida por 
um Secretário, indicado pelo Ministro de Estado de Justiça e nomeado pelo Presidente da República. ${ }^{5}$

Na prática a SEDE, foi criada para não asfixiar o CADE, visto possuir competência para dirimir e orientar a coletividade das boas condutas de marcado, instruindo-a sobre a diversas formas de infração da ordem econômica, e os modos de sua prevenção e repressão.

Assim, a SEDE pode instaurar processo administrativo para apuração e repressão de infrações ou providênciar diligências de órgãos, autoridades, entidades públicas ou a quaisquer pessoas, que se fizerem necessários.

Orienta também a SEDE os órgãos da administração pública quanto a adoção de medidas necessárias ao cumprimento da lei em questão.

Portanto, a Secretaria de Direito Econômico funciona como um tentáculo importante de sustentação do CADE, dando-lhe maior vigor para desempenhar a sua competência legal.

A Lei $n^{\circ} 8.884 / 94$ aplica-se às pessoas físicas ou jurídicas de direito público ou privado, abrangendo as associações de entidades ou pessoas, constituídas de fato ou de direito, ainda que temporariamente, com ou sem personalidade jurídica, mesmo que exerçam atividade sob regime de monopólio legal. ${ }^{6}$

Sendo que as decisões do Plenário do CADE, que condene o representado ao pagamento de uma multa ou que imponha obrigação de fazer ou não fazer, constitui título executivo extrajudicial, ${ }^{7}$ tendo preferência sobre as demais espécies de ação, exceto habeas corpus e mandado de segurança. ${ }^{8}$

$\mathrm{Na}$ hipótese da execução que tenha por objeto exclusivamente a cobrança de multa pecuniária será feita de acordo com o disposto na Lei $n^{\circ} 6.830$, de 22 de setembro de $1980 .^{9}$

Já para a execução que tenha por objeto, além da cobrança de multa, o cumprimento de obrigação de fazer ou não fazer, o Juiz estará autorizado, pelo artigo 62, da Lei $n^{\circ} 8.884 / 94$, a conceder a tutela específica da obrigação, ou determinar providências que assegurem o resultado prático equivalente ao do adimplemento, sendo permitido, conforme a gravidade do caso, a intervenção na empresa executa$\mathrm{da},{ }^{10}$ com a finalidade de ver acatada e cumprida as decisões do CADE. ${ }^{11}$

Apesar do art. 50, da Lei n 8.884/94 proclamar que as decisões do CADE não comportam revisão no âmbito do Poder Executivo, sendo de imediato executadas, nas decisões relativas a atos de concentração, é admitido o recurso hierárquico ao Ministro da Justiça, que poderá recebê-lo no duplo efeito ou não, como se verifica

5 Art. 13, da Lei ${ }^{\circ} 8.884 / 94$.

6 Art. 15, da Lei ${ }^{\circ} 8.884 / 94$.

7 Art. 60, da Lei $n^{\circ} 8.884 / 94$.

8 Art. 68, da Lei $n^{\circ} 8.884 / 94$.

9 Art. 61, da Lei $n^{\circ} 8.884 / 94$.

10 Art. 63, da Lei $n^{\circ} 8.884 / 94$.

11 Pelo fato do CADE ser uma Autarquia Federal, as açōes movidas por ele ou que sejam propostas contra o respectivo conselho, serão ajuizadas na Justiça Federal. 
na ementa do r. despacho do então Ministro da respectiva pasta è época e atual Ministro do STF, Nelson A. Jobim: ${ }^{12}$

“As decisões do CADE relativas a atos de concentração admitem recurso hierárquico ao Ministro da Justiça, que poderá recebê-lo, discricionariamente, em seus efeitos suspensivo e/ou devolutivo. Impõe-se o princípio da hierarquia funcional, para resguardo da unicidade e coerência administrativas".

Para não pairar dúvida ao intérprete, o então Ministro da Justiça já nominado, fez um "divisor de águas" sobre as decisões terminativas, abrangidas pelo art. 50 da Lei $n^{\circ} 8.884 / 94$, que são as que versam sobre práticas infrativas (condutas ilícitas), e os julgamentos de atos concentrados, que se encaixam nas ilicitudes elencadas pelo legislador. Neste último caso o Ministro afastou o óbice recursal e admitiu-o, sob as seguintes justificativas, dentre outras:

"Nos termos da lei, recursos administrativos são incabíveis, no âmbito do Poder Executivo, das decisões do CADE, em se tratando de práticas infrativas. Este caso - decisão sobre prática infrativas - a legislação deu caráter terminativo aos julgamentos do CADE, especialmente porque não haveria necessidade de se buscar novos posicionamentos administrativos em matéria cuja apreciação judiciária seria mais conveniente, por se tratar de conduta ilícita.

Esta, todavia, não foi a orientação adotada pela lei na hipótese de julgamento pelo CADE, de atos de concentração.

Se tivesse o órgão entendido que, no caso em exame, o ato era infrativo, o procedimento recursal estaria vinculado ao disposto no artigo 50. Todavia, o legislador agiu com judiciosa cautela, evitando vincular procedimentos de apreciação de ato de concentração aos procedimentos destinados a apreciar práticas infrativas. Assim circunscreveu a mens legis, em face da diferença conceitual em qualitativa dos atos a serem apreciados por um e outro procedimento. Tudo porque o ato de concentração é um fato temporal, gerador de consequiências, lícitas, e a prática infrativa é um ato ilícito sancionado.

$O$ ato de concentração é um ato complexo que relaciona a legislação vigente e a política econômica governamental, o que não significa que possa vir a ser infrativo, nas formas prescritas na lei. Mas, este não foi o caso, porque se o fosse, caberia a consequiência punitiva, que não houve, tendo o CADE determinado apenas, a desconstituição, em parte, do ato apreciado, o que significa que parte dele está aprovado."

12 Despacho ${ }^{\circ} 266$, de 13 de novembro de 1995, do Ministro da Justiça no Recurso Hierárquico da Siderúrgica Laisa S.A., DOU de 14.11.1995, p. 18.223 e segs. 
Deixando de lado se o ato a ser julgado é infrativo ou não, vejo com certa cautela a dicção do artigo 50 , da Lei $n^{\circ} 8.884 / 94$, que pacifica o entendimento de que as decisões do CADE são irrecorríveis, pois como um tribunal administrativo sua atuação não pode ser dissociada da regra da ampla defesa a que alude o art. $5^{\circ}, \mathrm{LV}$, da CF. Ou seja, o direito subjetivo constitucional do due process of law, contido no art. $5^{\circ}$, da Lei Maior, garante "o contraditório e a ampla defesa, com os meios e recursos a ela inerentes", não podendo a Administração Pública impedir que o administrado utilize o direito de petição e de ampla defesa nas demandas administrativas, suprimindo o recurso hierárquico.

Apesar de constar no art. 50, da Lei $n^{\circ} 8.884 / 94$ a irrecorribilidade das decisões do CADE, esta norma agride, como já dito, o preceito constitucional fundamental da ampla e necessária defesa do administrado, que no pedido de revisão ou recurso hierárquico ao Ministro de Estado da Justiça possui a esperança de ver revertido possível posicionamento contrário aos seus legítimos interesses. ${ }^{13}$

Isto porque, o direito ao duplo grau de jurisdição, apesar de não estar explicitado em nenhuma norma constitucional, abriga-se, induvidosamente no conteúdo do devido processo legal, consoante entendimento da doutrina especializada. ${ }^{14}$

Nada mais expressivo do que trazer à lume a visão do emérito processualista Humberto Theodoro Júnior: ${ }^{15}$

"O instituto do recurso vem sempre correlacionado com o princípio do duplo grau de jurisdição, que consiste na possibilidade de submeter-se a lide a exames sucessivos, por Juizes diferentes, como garantia de boa solução (Barbosa Moreira, Comentários ao CPC, vol. V, $\mathrm{n}^{\circ} 107$ ).

Embora inexista texto expresso na Constituição, a doutrina ensina que o duplo grau de jurisdição está ínsito em nosso sistema Constitucional (José Frederico Marquês, Instituições de Direito Processual Civil, vol. IV, p. 210, apud Barbosa Moreira, op. e loc. cit.)."

Todavia, para não conferir maior importância a inconstitucionalidade declinada nesta oportunidade, com desvio do tema central, deixaremos para outra ocasião uma maior reflexão sobre a legalidade do supracitado artigo 50 , da Lei ${ }^{\circ} 8.884 / 94$.

13 "Das decisões do CADE, qualquer que seja sua natureza, não cabe revisão no âmbito do Poder Executivo, devendo-se promover de imediato a execução judicial, em caso de descumprimento, comunicando-se o fato ao Ministério Público, para as providências de sua alçada. $O$ bem Jurídico protegido pela Lei de Defesa da concorrência é a coletividade e não a Política Econômica ou Industrial do Estado." (CADE - Ata da 14" Sessão Extraordinária, de 15 de novembro de 1995, Ato de Concentração n⿳ 16/94, Conselheiro Presidente, Carlos Eduardo Vieira de Carvalho, DOU de 6.11.95, pág. 684).

14 Cf. Luís Roberto Barroso, “Temas de Direito Constitucional”, 2000, ed. Renovar, pág. 585.

15 Humberto Theodoro Júnior, Direito Processual Civil, 1997, pág. 551. 


\section{Das infrações da ordem econômica julgadas pelo CADE}

O CADE, Tribunal Administrativo nos termos do art. 3 da Lei ${ }^{\circ} 8.884 / 94$, não tem atribuições e funções limitadas ao julgamento dos casos de sua competência, eis que além de apreciar e decidir as infrações estrito senso à ordem econômica, oficia as autoridades na busca de medidas saneadoras, além de peticionar ao Poder Judiciário como parte ou assistente.

Geralmente o tribunal administrativo não possui personalidade própria ${ }^{16}$ e não funciona como órgão consultivo, diferentemente do CADE, a quem compete defender o bem jurídico da ordem econômica, podendo intervir ou ser questionado perante a Justiça Federal, exatamente para manter acesa e viva a livre concorrência econômica, temperada pelos limites da lei.

Na sua missão, o Conselho possui como objetivo impedir que ocorra infração da ordem econômica, ou caso ela esteja configurada, reestabelecer a normalidade, através de medidas saneadoras.

Constituem infração da ordem econômica, independentemente de culpa, os atos sob qualquer forma manifestados, que tenham por objeto produzir os seguintes efeitos, mesmo que ainda não sejam alcançados: ${ }^{17}$

a) limitar, falsear ou de qualquer forma prejudicar a livre concorrência;

b) dominar mercado relevante de bens ou serviços;

c) aumento arbitrário dos lucros;

d) exercício abusivo da posição dominante.

A conquista de mercado salutar, sem a caracterização de infração a ordem econômica, é aquela resultante de processo natural fundado na maior eficiência de agente econômico em relação a seus competidores. ${ }^{18}$

Já a posição dominante - infração capitulada no inciso IV do art. 20, da Lei $\mathrm{n}^{\circ}$ 8.884/94 quando é exercida de forma abusiva - é caracterizada quando uma empresa ou grupo de empresas controla parcela substancial de mercado relevante, como fornecedor, intermediário, adquirente ou financiador de um produto ou tecnologia a ele relativa. ${ }^{19}$

Sendo que a posição dominante a que se refere a lei é presumida quando a empresa ou grupo de empresas controla $20 \%$ do mercado relevante, podendo este percentual ser alterado pelo CADE para setores específicos da economia.

Além das hipóteses já narradas, $o$ art. 21 , da Lei $n^{\circ} 8.884 / 94$, carateriza também como infração da ordem econômica os seguintes casos:

a) fixar ou praticar, em comum acordo com concorrente, preços e condições de venda de bens ou de prestação de serviços.

16 É caso do Tribunal Marítimo, do Superior Tribunal de Justiça Esportiva e muitos outros órgãos judicantes administrativo.

17 Art. 20, da Lei $n^{\circ} 8.884 / 94$.

$18 \S 1^{\circ}$ do art. 20 , da Lei $n^{\circ} 8.884 / 94$.

$19 \S 2^{\circ}$ do art. 20 , da Lei $n^{\circ} 8.884 / 94$. 
b) obter ou influenciar a adoção de conduta comercial uniforme ou concertante entre concorrentes;

c) dividir mercados de serviços ou produtos acabados ou semi-acabados, ou as fontes de abastecimento de matérias-primas ou produtos intermediários;

d) limitar ou impedir o aceso de novas empresas no mercado;

e) criar dificuldades á constituição, ao funcionamento ou ao desenvolvimento de empresa concorrente ou de fornecedor, adquirente ou financiador de bens ou serviços;

f) impedir o acesso de concorrente às fontes de insumos, matérias-primas, equipamentos ou tecnologia, bem como aos canais de distribuição;

g) exigir ou conceder exclusivamente para divulgação de publicidade nos meios de comunicação de massa;

h) combinar previamente preços ou ajustar vantagens na concorrência pública ou administrativa;

i) utilizar meios enganosos para provocar a oscilação e preços de terceiros;

j) regular mercados de bens ou serviços, estabelecendo acordos para limitar ou controlar a pesquisa e o desenvolvimento tecnológico, a produção de bens ou prestação de serviços, ou para dificultar investimentos destinados à produção de bens ou serviços ou à sua distribuição;

k) impor, no comércio de bens ou serviços, a distribuidores, varejistas e representantes, preços de revenda, descontos, condições de pagamento, quantidades mínimas ou máximas, margem de lucro ou quaisquer outras condições de comercialização relativos a negócios destes com terceiros;

l) discriminar adquirentes ou fornecedores de bens ou serviços, ou de condições operacionais de venda ou prestação de serviços;

$m$ ) recusar a venda de bens ou a prestação de serviços, dentro das condições de pagamento normais aos usos e costumes comerciais;

n) dificultar ou romper a continuidade ou desenvolvimento de relações comerciais de prazo indeterminado em razão de recusa da outra parte em submeter-se a cláusulas e condições comerciais injustificáveis ou anticoncorrenciais;

o) destruir, inutilizar ou açambarcar matérias-primas, produtos intermediários ou acabados, assim como destruir, inutilizar ou dificultar a operação de equipamentos destinados a produzi-los, distribuí-los ou transportá-los;

p) açambarcar ou impedir a exploração de direitos de propriedade industrial ou intelectual ou de tecnologia;

$r$ ) abandonar ou destruir lavouras ou plantações, sem justa causa comprovada;

s) vender sem justificativa plausível mercadoria abaixo do preço de custo;

t) importar bens abaixo do custo no país exportador, que não seja signatário dos códigos antidumping ou de subsídios do GATT.

$u$ ) interromper ou reduzir em grande escala a produção, sem justa causa comprovada;

v) cessar parcial ou totalmente as atividades da empresa sem justa causa comprovada;

$x$ ) reter bens de produção ou de consumo, exceto para garantir a cobertura dos custos de produção; 
y) subordinar a venda de um bem à aquisição de outro ou à utilização de um serviço, ou subordinar a prestação de um serviço à utilização de outro ou à aquisição de um bem;

z) impor preços expressivos, ou aumentar sem justa causa o preço de bem ou serviço.

A rigor estes são os casos em que o CADE foca a sua alça de mira, para combater a atuação predatória que configure a prática de infração da ordem econômica, punindo os responsáveis com multas, proibição de contratar com instituições financeiras oficiais e participar de licitações tendo por objeto aquisições, alienações, realização de obras e serviços, concessão de serviços públicos junto à Administração Pública Federal, Estadual, Municipal e do Distrito Federal, bem como entidades das respectivas administrações indiretas, por prazo não inferior a 5 anos, dentre outras sanções.

\section{O CADE e o contrato administrativo}

A Lei $\mathrm{n}^{\circ} 8.884 / 94$ se aplica às pessoas físicas e jurídicas de direito público ou privado, consoante determinação expressa do seu artigo 15.

Fulcrado em sua competência legal, o CADE vem se insurgindo contra aumento de tarifa de transporte público concedido por ente municipal, por entender que ela é abusiva, além de focar também sua ótica para determinados Editais de licitação, que por regularem o certame competitório, precedem a celebração dos respectivos contratos administrativos.

Nessa vertente, o CADE tem atuado em várias situações que envolvem a contratação pública, e para facilitar as respectivas análises e enfrentamento do tema, serão abordados, com o objetivo de demonstrar nos precedentes a linha de condução do Conselho.

Fixou competência o CADE para coibir aumento abusivo de tarifa de transporte público majorado por municipalidade, como se constata do seguinte julgado: ${ }^{20}$

“A Lei n 8.884 , de 1994, confere ao CADE competência para conhecer e julgar não apenas de matéria ligada à concorrência. Assim, tem o Conselho competência para apreciar eventual abusividade de aumento de preços públicos e de tarifas de serviços públicos."

No seu voto condutor, o eminente Conselheiro Relator, Dr. Edgard Lincon de Proença Rosa, justifica a competência do CADE para o caso narrado, em primeiro plano, pela revogação do art. 15 da Lei ${ }^{\circ} 8.884 / 94$ e, por derradeiro, pela razão do artigo 92, da mesma Lei, revogar as disposições em contrário, referindo expressa-

20 CADE Averiguação Preliminar nº 08000.011794/94-75, de 16 de fevereiro de 1996, Relator Conselheiro Edgard Lincon de Proença Rosa, representante: Departamento de Proteção e Defesa Econômica - DPDE, representado: Município do Rio de Janeiro, DOU e 11.03.96, p. 3.959. 
mente as Leis $\mathrm{n}^{\text {os }} 4.137 / 62,8.158 / 91$ e $8.002 / 90$, mantendo, contudo o disposto no art. 36, da Lei $n^{\circ} 8.880$, de 27 de maio de 1994, que permite que:

“Art. 36. O Poder Executivo, por intermédio do Ministério da Fazenda, poderá exigir que, em prazo máximo de 5 dias úteis, sejam justificadas as distorções apuradas quanto a aumentos abusivos de preços em setores de alta concentração econômica, de preços públicos e de tarifas de preços de serviços públicos."

A seguir o citado Conselheiro arremata:

"Para mim, a Lei $n^{\circ}$ 8.884/94 outorga ao CADE competências outras que não, exclusivamente, as que ele quer exercer. Vou repetir uma coisa que disse lá, por outras palavras: $O$ Conselho não pode pretender ser somente, uma espécie de Tribunal Administrativo em matéria de concorrência (item 2.8 daquele voto).

Só porque isto não me parece corresponder a abrangência maior - não muito maior, mas maior - com que aquela lei alberga a Autarquia."

Em que pese o respeito pela ótica autorizada pelo voto, ouso discordar do mesmo, por vários motivos, sendo que o primeiro deles reside no fato do art. 36 , da Lei $\mathrm{n}^{\circ} 8.880 / 94$, permitir apenas, por intermédio do Ministério da Fazenda, que haja justificação sobre possíveis distorções apuradas quanto a aumentos abusivos de tarifas de preços de serviços públicos, postura que não se confunde com a competência do CADE, que é vinculada ao Ministério da Justiça. ${ }^{21}$

Ademais, o legislador se preocupou com este controle efetuado pelo Ministério da Fazenda pelo fato de, em 1994, ano da edição da respectiva Lei $n^{\circ} 8.880$, estar implantando o plano de estabilização monetária que acabou no ano seguinte, desaguando no plano real. Assim, o eminente Conselheiro Relator justifica a intervenção do CADE com base em preceito legal claro e objetivo, que confere apenas ao Ministério da Fazenda a prerrogativa de exigir explicações necessárias dos órgãos e empresas responsáveis por preços abusivos de tarifas cobrados por concessionário, que em tese, poderia colocar um perigo o aludido plano de estabilização econômica.

Como guardião do Plano Econômico, cabe ao Ministério da Fazenda, e não ao CADE, que é vinculado ao Ministério da Justiça, a supervisão e repressão de possíveis irregularidades.

Pois bem, caso fosse ultrapassada esta barreira legal, o que se admite apenas para o exercício dos desdobramentos legais possíveis, haveria outro grave entrave contra a ótica do CADE, qual seja, a relação da tarifa pública não cria dominação de mercado e nem gera concorrência ruinosa, pois a concessão pressupõe necessariamente a vitória de determinada empresa em uma concorrência pública, explorando a mesma o seu mercado.

21 Art. $3^{\circ}$, da Lei $n^{\circ} 8.884 / 94$. 
Estaria, portanto, a presente hipótese fora do espectro constitucional previsto no $\S 4^{\circ}$ do art. 173 , que claramente autorizou a lei a reprimir o abuso do poder econômico gerador de dominação dos mercados, eliminação da concorrência e aumento arbitrário dos lucros para hipóteses diversas daquelas que são verificadas na concorrência pública.

Quanto a dominação dos mercados e eliminação da concorrência a que alude o respectivo preceito constitucional, o processo licitatório descarta estes enquadramentos, visto que o mercado é unitário exercido pelo vencedor do certame licitatório.

Ademais, qualquer tipo de reclamação quanto à cobrança de tarifas partiria dos usuários, revelando uma situação de consumo, que refoge à competência do CADE. ${ }^{22}$

Nessa moldura, o simples aumento de preços públicos ou tarifas não configura lucro arbitrário, eis que decorre da exigência de se manter intacta a equação financeira do contrato administrativo.

Assinale-se, desde logo, que a tarifa, no atual sistema jurídico administrativo, é a constante do contrato, e terá de ser obrigatoriamente preservada durante toda a sua duração, mediante os mecanismos de revisão - tomado em sentido lato -, à abranger os reajustes periódicos, revisões 'stricto sensu', ou os reposicionamentos (art. $9^{\circ}$, da Lei $\mathrm{n}^{\circ} 8.987 / 95$ ).

Constitui, portanto, obrigação básica da contratante - poder concedente, e, em correspondência, direito fundamental da contratada - concessionária, a manutenção do valor do preço contratual, mercê dos necessários ajustes, em face das mutações administrativas, econômicas e de outras naturezas, que se forem sucedendo.

Compreendente-se nesta evolução - determinar os obrigatórios ajustes tarifários - os atos do Poder Público, contratante ou não, que caracterizam o fato do princípe assim como as modificações da conjuntura econômica.

Nenhum segmento mais contratual, do que esse binômio oriundo da obrigação da contratante $\mathrm{X}$ direito da contratada, em sede da álea administrativo-econômica.

O serviço pelo preço é a tradução de princípio que governa a contratação administrativa em geral, e, muito especialmente, na modalidade da concessão de serviço público, em virtude de sua mais prolongada duração e dos capitais investidos pela concessionária: trata-se do princípio da prevenção da

“...relação que as partes pactuaram inicialmente entre os encargos do contrato e a retribuição da administração para a justa remuneração da obra, serviço (...)" 23

E coube à Constituição de 1988 referendar a garantia do equilíbrio econômico e financeiro de todos os contratos administrativos, pois o inciso XXI do art. 37

22 O Próprio CADE já teve a oportunidade de pacificar que não é competente para apreciar as matérias que envolvam o Código de Defesa do Consumidor: "As matérias afetas ao Código de Defesa do Consumidor refogem à competência do CADE" (Representação $n^{\circ}$ 104/93, Relator Conselheiro Paulo Dyrceu Pinheiro, DO de 10.10.96, p. 20.296.

23 Art. 65, II, da Lei $n^{\circ} 8.666 / 93$. 
estende este salutar princípio a todos os pactos com a Administração Pública, deixando de focar apenas o contrato de concessão, como ocorria no texto passado.

Ciente desta realidade, os Tribunais Superiores mantém intacta a garantia contratual declinada, como se infere no presente aresto da $1^{\text {a }}$ Turma do STJ: ${ }^{24}$

"É lícito ao poder concedente alterar, unilateralmente, as cláusulas objetivas do serviço, e, até agravar os encargos ou as obrigações do concessionário, desde que reajuste remuneração estipulada, evitando a quebra do equilíbrio econômico-financeiro do contrato."

Já na $2^{\mathrm{a}}$ Turma do Superior Tribunal de Justiça $\mathrm{a}^{25}$ foi submetida a julgamento a questão específica de permissão de serviço público de transporte coletivo, tendo sido decidido que também aí é aplicável o princípio do equilíbrio econômico-financeiro do pacto administrativo. Da ementa deste acórdão se destaca o seguinte trecho:

"Permissionárias de transporte coletivo de passageiros. Insurgência contra cobrança instituída pela Resolução SMDU-42, do Sr. Secretário de Habitação de Desenvolvimento Urbano do Estado de São Paulo. Taxa. Preço Público. Tarifa. Diferenciação. Poder de polícia. Contrato Administrativo, observância ao princípio da equação econômica financeira."

Por estas razões, entendemos que o CADE não possui competência para rever aumento de tarifa de serviço público, pois "o controle das despesas decorrentes dos contratos e demais instrumentos regidos" pela Lei $\mathrm{n}^{\circ}$ 8.666/93 - abrangem-se neste contexto, a lei de concessões - " será feito pelo Tribunal de Contas competente, na forma da legislação pertinente, ficando os órgãos interessados da Administração responsáveis pela demonstração da legalidade e regularidade da despesa e execução, nos termos da Constituição e sem prejuízo do sistema de controle interno nela previsto. ${ }^{26}$

Todavia, comprovando que o simples aumento de tarifas (preços) públicos, por si só, não configura matéria afeta ao CADE, por não materializar abuso do poder econômico que demonstre a dominação dos mercados, com o extermínio da concorrência, configurando aumento arbitrário dos lucros, nunca é demais invocar o seguinte precedente do respectivo Conselho: ${ }^{27}$

"O simples aumento de preços, por si, não configura matéria para exame do CADE. É preciso a tal desiderato que aquele configure lucro arbitrário ou obtido por maios artificiosos, como resultado da restrição à concorrência e abuso de posição dominante no mercado."

24 STJ, Rel. Min. Demócrito Reinaldo, $1^{*}$ T., RMS n 1.681-0-TO, in Revista do STJ, vol. 52, ps. $305 / 306$.

25 STJ, Rel. Min. Américo Luiz, $2^{2}$ T., RMS n ${ }^{\circ}$ 582-SP, in RDA 186: 133.

26 Art. 113, da Lei ${ }^{\circ} 8.666 / 93$.

27 CADE, Representação n $79 / 92$, de 18.12.96, Rel. Conselheira Lúcia Helena Salgado. 
Por fim, como relação tarifária não atinge o liame configurador de conduta anticoncorrencial, nem infração - lato senso - à ordem econômica, falece competência ao CADE para invadir a relação contratante $x$ contratada, que poderia ser contestada, em tese, por qualquer usuário do serviço, ${ }^{28}$ caso ela extrapolasse a razoabilidade.

Extrai-se, portanto, da análise do primeiro caso, que malgrado a amplitude das disposições contidas na Lei $n^{\circ} 8.884 / 94$, é mister que a sua interpretação seja orientada pelo princípio da legalidade, plasmado na Constituição. E, segundo a Constituição, o combate e a repressão ao abuso do poder econômico depende de lei (art. 173, $\S 4^{\circ}$ ). Ela somente poderá ser exercitada nos limites da lei. Qualquer poder que é exercido de uma forma ampla, geral e irrestrita, mesmo que não seja consciente, torna-se arbitrário.

Assim, o CADE, amarrado à lei, deverá preservar, dentre outros valores, a propriedade e o planejamento privado da produção, protegendo-os contra a intervenção indevida. Afinal o princípio da legalidade, segundo o qual "ninguém será obrigado a fazer ou deixar de fazer alguma coisa senão em virtude da lei, ${ }^{29}$ vincula toda a Administração Pública.

Nessa moldura, o CADE não pode extrapolar os limites da lei para intervir nas tarifas públicas de concessão de serviço de transporte urbano.

Não possui "cheque em branco" o Conselho para preenchê-lo como bem entender, consoante ficou consignado no voto vista proferido no Processo Administrativo ${ }^{\circ} 21$ do $\mathrm{CADE}^{30}$

"Na qualidade de agente dessa política, o CADE, no exercício da sua função adjudicadora, deve se certificar que está cumprindo a lei, nem mais nem menos. A discricionariedade não é um cheque em branco. Daí, o órgão deve tratar os conceitos ou padrões normativos com instrumental racionalidade, afastando, sempre que puder, o risco de ferir o sendo econômico das coisas."

Em outro caso, especificamente no Leilão de privatização da EMBRAER, o CADE foi acionado pelo Sindicato dos Engenheiros no Estado de São Paulo, que alegou ofensa à regra editalícia, por ocorrer vedação de participação de entidades da Administração direta ou indireta no leilão.

De forma acertada, o Conselho rechaçou a citada representação, ficando assim ementada a sua decisão: ${ }^{31}$

28 “(...) O CADE goza de uma competência adjudicadora, no que se segure à repressão das condutas anticoncorrenciais, e de uma competência auxiliar que opera no domínio das infrações lato senso à ordem econômica, excluídas desta as infrações qualificadas pelo direito do consumidor." (CADE, Processo Administrativo $n^{\circ}$ 21/91, de 11 de dezembro de 1996, Rel. Conselheiro Antônio Fonseca). 29 Art. $5^{\circ}$, II, da CF.

30 Processo $n^{\circ} 21 / 91$ de 11 de dezembro de 1996, Rel. Conselheiro Antônio Fonseca.

31 CADE, voto na Averiguação Preliminar nº 0800.025366-95/95-16, de 25 de setembro de 1996, Rel. Cons. Antônio Fonseca, $D O$ de 10.11.96, p. 20.296. 
"Queixa de ofensa a regra editalícia em licitação pública, sem absoluta implicação com a defesa da concorrência, escapa da esfera de atuação do CADE."

Em outro julgado, o CADE apreciou cláusulas de edital de licitação pública e convênio que fixavam preços com base em tabela estabelecida por entidade de classe. Nessa oportunidade, o Conselho ${ }^{32}$ deixou expresso que:

"É inadmissível em editais de licitações públicas e convênios e outros instrumentos celebrados pela Administração Pública a exigência de fixação de preços de acordo com tabela estabelecida por entidade de classe."

A restrição do CADE, no caso sub-examem, deve-se ao fato dele ter condenado a influência da tabela de honorários médicos da Associação Médica Brasileira, por entender que este critério possui o efeito de uniformizar a conduta de concorrentes.

E fulcrado na sua competência legal, o CADE oficiou aos Ministérios da Administração e Reforma do Estado e Ministério da Saúde, com a recomendação para deixarem de fazer constar dos editais de licitação pública e da redação de convênios e instrumentos assemelhados a exigência de se fixar o preço dos serviços médicos vinculados a tabela de honorários da categoria, fixada pela AMB.

Esta sintonia é perfeita, pois o CADE, no exercício de sua competência, não possui o poder de cancelar ou revogar licitação pública ${ }^{33}$ pois compete ao órgão público responsável pelo certame, aferir as razões de conveniência e oportunidade da respectiva concorrência. Cabe, entretanto, o juízo de valor do Conselho sobre o "abuso do poder econômico que crie a dominação dos mercados, à eliminação das concorrências e ao aumento arbitrário dos lucros" ${ }^{34}$ com a recomendação de condutas, no intuito de abolir procedimentos que configurem abalo à salutar concorrência.

Assim, o cade não possui competência para adentrar à legalidade das concorrências públicas, devendo apenas ater-se as condutas anticoncorrenciais que porventura possam estar presentes tanto nas cláusulas dos editais dos respectivos certames, bem como em eventuais condutas promovidas pelas empresas licitantes na competição.

E uma grave atitude anticoncorrencial é aquela em que se configura o favorecimento ou facilitação sistemática a uma empresa ou grupo de empresas, com

32 CADE, Processos Administrativos nos $155 / 94$ e 164/94, de 19 de junho de 1996, Rel. Conselheira Lúcia Helena Salgado, $D O$ de 18.7.96, p. 13.195.

33 "Embora possa o CADE, no exercício de sua competência adjudicatória, posicionar-se, mediante expediente fundamentado, pelo cancelamento de licitação pública, não pode ele revogá-lo, porque tal atitude configura ato de soberania do órgão responsável pelo certame." (CADE, Representação $n^{\circ}$ 6/94, julgado em 28 de maio de 1997, Rel. Conselheiro Paulo Dyrceu Pinheiro, DO de 13.06.97, p. 14.013).

34 Art. $173, \S 4^{\circ}$ da CF. 
domínio de mercado individual, gerando efeitos adversos à concorrência pública promovida através do procedimento licitatório.

Não resta dúvida que é de sobremaneira difícil provar uma relação de conluio ilícito, onde o agente público, em detrimento da competição, foca o seu desejo pelo subjetivismo, abandonando o caráter objetivo que deve nortear todo o procedimento da licitação pública, e "pinça" determinado competidor como seu preferido.

Todavia, esse tema não ficou em branco para o CADE, que em expressiva passagem, posicionou-se sob o seguinte ângulo: ${ }^{35}$

"Em tema de concorrência pública, havendo possibilidade de assistência ou contribuição da autoridade administrativa em favor de um licitante, decorrendo esta de uma relação de conluio ilícito, o CADE pode julgar e punir a conduta anticoncorrencial do agente privado independentemente da assistência."

O Conselheiro Relator do caso supratranscrito expresso em outro julgado ${ }^{36}$ que:

“2. A Administração Pública pode contribuir para uma prática anticoncorrencial que se qualifica como ato de comércio, a exemplo de conluio envolvendo servidores públicos para beneficiar agentes privados participantes de licitações administrativas, com possibilidade de o resultado afetar as condições de marcado ou concorrência. Hipótese em que o CADE pode atuar, no âmbito da sua competência prevista na Lei $n^{\circ} 8.884 / 94$, independentemente de a licitação ter sido julgado boa pelo Poder Judiciário ou pela Corte de Contas.

3. Em princípio, o favorecimento ou facilitação sistemática a uma empresa ou grupo de empresas, com domínio de mercado individual ou coletivo, ex $v i$ licitações administrativas, poderá gerar efeitos adversos à concorrências do tipo previsto no inciso $V$, do art. 21 , da Lei $n^{\circ} 8.884 / 94$. A licitação casada, adotada pelo edital de licitação, pode constituir meio de favorecimento. A critério da Administração, a licitação pode envolver mais de um objeto relacionados entre si desde que demonstrada alguma eficiência do fornecimento casado de bens ou serviços. A exclusividade, mesmo reconhecida por lei, não legitima necessariamente o fornecimento casado."

O único reparo que se faz ao voto do eminente Conselheiro Antônio Fonseca, pertine à referência à atuação do $\mathrm{CADE}$, mesmo quando a hipótese versada já tenha sido julgada pelo Poder Judiciário. Ora, o CADE como um Tribunal Administrativo se curva às decisões judiciais, que por serem soberanas radiam os seus efeitos para

35 CADE, Conselheiro Relator, Antônio Fonseca, Representação $n^{\circ} 165 / 92$, de 1 de outubro de 1997, DOU de 27.11.97, p. 24.157.

36 CADE, Cons. Relator Antônio Fonseca, Representação $n^{\circ} 165 / 92$, julgado em 01.10.97, DO de 27.10 .97 , p. 24157. 
as repartições públicas. Portanto, se houver uma decisão judicial transitada em julgado ou não, que referende determinado procedimento licitatório, é defeso a qualquer outra esfera de poder constituído todavia, tanto o contrato administrativo como os editais de licitação somente sofrem o controle de seu mérito pela esfera administrativa pelo Tribunal de Contas. ${ }^{37}$

\section{Reflexões finais}

O breve estudo ora realizado não se destina a uma reavaliação do CADE, e da sua notória eficiência no combate as infrações econômicas tarefa básica dentre as que constituem a sua competência.

Registre-se, contudo, que o presente tema merece esta reflexão por estar à espera de um autor.

E o direito efetivamente encontra a sua grande evolução quando várias cabeças começam a pensar sobre o mesmo assunto, com respostas rápidas e objetivas às indagações surgidas.

Assim, não pretende o autor criticar a atuação do CADE, pois ele realiza o salutar e necessário controle do poder econômico quando desempenhado de forma lesiva aos mercados, resultando da eliminação da concorrência. Dessa forma, a independência e altivez dos seus membros possui o condão de conduzir o Conselho a um lugar de destaque no cenário jurídico, econômico e político.

Por esta razão é que tivemos a preocupação de deixar bem nítida a visão dos eminentes Conselheiros do CADE no campo da contratação pública, para que o leitor reflita sobre os pontos jurídicos levantados, com o intuito de avaliar os desdobramentos legais desenvolvidos.

Destarte, após as análises de alguns casos concretos, se extrai a conviç̧ão de que o CADE não possui competência legal para se insurgir contra o contrato administrativo lato senso, e nem quanto a legalidade de um processo de licitação, em virtude do $\S 4^{\circ}$, do art. 173 , da CF fixar as balizas de sua atuação.

É necessário que se estabeleça logo a idéia de que o CADE possui a missão de impedir que ocorra infração da ordem econômica e, caso ela já esteja configurada, o seu necessário combate, para que haja o retorno da normalidade

Constitui infração da ordem econômica, os atos que limitam ou prejudicam a livre concorrência, com o exercício abusivo da posição dominante, aumento dos lucros de forma arbitrária e a dominação do mercado relevante de bens ou serviços, entendemos que o contrato administrativo de concessão de serviço de transporte de determinada municipalidade, citado como referência, fica imune da competência do CADE, que não possui legitimidade para aferir a legalidade do aumento da correspondente tarifa.

O contrato Administrativo, precedido do certame licitatório, está retirado das hipóteses configuradas de infração da ordem econômica, que desencadeia a dominação de mercados. 
E, sendo assim, não compete ao CADE adentrar no mérito do mesmo, e nem coibir aumento "abusivo" de tarifa de transporte público fixado por ente de direito público competente, como já narrado alhures.

Qualquer irresignação quanto as cláusulas do contrato ou dos aumentos tarifários deverão ser endereçadas para os Tribunais de Contas respectivos ou para os órgãos de controle interno de cada poder, dependendo da hipótese concreta.

Por outro lado, o pagamento efetuado pela utilização de um serviço público revela uma das espécies de consumo, onde o usuário do serviço ou sua entidade de classe possuem a faculdade de ingressarem na via judicial para questionar abusividade tarifária, não se prestando o CADE para à substituição de tal jurisdição.

$\mathrm{O}$ aumento de tarifas (preços) públicas, em tese, não materializa abuso do poder econômico que estabeleça a dominação dos mercados, pois de acordo com a Constituição vigente, as obras, os serviços, as compras, alienações e as concessões devem obedecer ao princípio da garantia da equação econômica-financeira, sendo mantidas as condições reais e efetivas da proposta.

Qualquer excesso no reajuste da tarifa foge da esfera de competência do CADE, visto que o aumento abusivo do respectivo preço tarifário não caracteriza infração da ordem econômica elencado pela Lei $\mathrm{n}^{\circ}$ 8.884/94.

Além do mais, compete ao Tribunal de Contas, como órgão de controle externo, a função de fiscalizar contábil, financeira, orçamentária, operacional e patrimonialmente a União e as entidades da Administração Direta e indireta, quanto à legalidade, legitimidade, e economicidade das contas públicas. ${ }^{38}$

E inclua-se, neste controle externo, a cargo do Congresso Nacional, exercido com auxílio do Tribunal de Contas competente, o julgamento das contas dos administradores e demais responsáveis por dinheiro, bens, e valores públicos das diversas esferas das Administrações e daqueles que derem causa a perda, extravio ou outra irregularidade de que resulte prejuízo ao erário público. ${ }^{39}$

Nessa linha legal, a Constituição Federal, em seu art. 71, VIII, é bem clara em:

“VIII - Aplicar aos responsáveis, em caso de ilegalidade de despesa ou irregularidade de contas, as sanções previstas em lei, que estabelecerá, entre outras, cominações, multa proporcional ao dano causado ao erário."

Vê-se, portanto, que o ato administrativo que defere o aumento de tarifa pública se inclui no enredo constitucional de contas públicas, visto que mesmo ela sendo paga pelo usuário do serviço, é cobrada mediante a prestação de um serviço público outorgado pelo Estado.

Nessa condição, o Tribunal de Contas possui a competência para aferir se é abusivo ou não o reajuste tarifário deferido pelo poder concedente, e se ele seguiu a liturgia legal que norteia a matéria.

38 Art. 70 da CF.

39 Art. 71, I, da CF. 
Abra-se parêntese para registrar a arguta visão do eminente professor Carlos Roberto Siqueira Castro, ${ }^{40}$ para quem:

"Contudo, no que concerne ao mérito propriamente dito de atos especializados de controle externo a cargo do Tribunal de Contas, quando revestirem-se de natureza inequivocamente política, sou inclinado a pensar que a Corte de Contas está Constitucionalmente investida de autonomia técnica e de prerrogativas privativas e insubrogáveis pelos demais Poderes do Estado."

E não é outra a visão do Poder Judiciário, que pela voz do saudoso Min. Vitor Nunes Leal, deixou consignado no STF, ${ }^{41}$ que:

"Salvo nulidade decorrente de irregularidade formal grave ou de manifesta ilegalidade, é do Tribunal de Contas a competência exclusiva para julgamento das contas dos responsáveis por haveres públicos."

A fiscalização do Tribunal de Contas ganha relevo cada dia maior, em virtude do número crescente das delegações administrativas, nas formas tripartidas, constitucionalmente assentadas: autorização, permissão e concessão.

Sendo que a concessão, por ser um serviço delegado sob a permanente fiscalização do Tribunal de Contas, visto ser ele o responsável não só pelo controle das despesas públicas como também para a aferição da legalidade de aumento dos preços públicos. E tarifa é um preço público:

"O preço dos serviços públicos é traduzido em ato sob forma de tarifa, isto é, quando o preço de uma dada quantidade de serviço vem fracionado em unidade, ele se transforma em tarifa." 42

Sobre a natureza jurídica da tarifa, nada mais preciso do que trazer ao debate a posição de Laubadére:

"Nas relações entre o concedente e o concessionário, a questão da natureza jurídica da tarifa é mais discutida. A maioria dos autores que admitem a

40 Carlos Roberto Siqueira Castro, "A Atuação do Tribunal de Contas em Face da Separação dos Poderes do Estado", in Revista Î́bero-Americana de Direito Público, vol. II, ed. América Jurídica, pág. 10.

41 STF, Rel Min. Vitor Nunes Leal, MS n 55.821, Pleno, in Revista Forense, vol. 226, pág. 81.

42 Vicenzo Tangorra, Tratatto di Scienza della Finanza, ps. 436/437. José Cretella Júnior foca a tarifa com a seguinte ótica:

"Assim, dividido em unidades todo o serviço prestado por uma determinada empresa pública e estabelecido para cada espécie da mesma unidade e preço correspondente, estamos diante do sistema particular de tarifas dessa dada empresa" (Dos Contratos Administrativos, ed. Forense, 1997, p. 150). 
natureza mista da concessão de serviço público não hesitam em considerar a tarifa como parte das cláusulas regulamentares desta. Sem dúvida, as quantias autorizadas pelas cláusulas tarifárias correspondem a vantagens financeiras reconhecidas ao concessionário à guisa de remuneração, mas não é menos verdade que a tarifa constitui elemento essencial das regras de funcionamento do serviço público."

Não resta dúvida que por ser uma relação contratual, estabelecida entre concedente e concessionário, a tarifa sofre a fiscalização direta do Tribunal de Contas a quem compete aferir o controle de legalidade dos atos de índole financeira das Administração ${ }^{43}$ incluindo-se neste contexto os aumentos ou as revisões.

Adentrando, inclusive, no controle do mérito da despesa pública, a Constituição Federal permite ao Tribunal de Contas verificar se o aumento de uma tarifa atingiu o seu objetivo adequadamente e com o menor custo para a Administração, sem desatrelar-se da equação-financeira do mesmo.

Espancando qualquer dúvida sobre a legalidade do controle do Tribunal de Contas sobre as tarifas públicas e dever de se prestar contas, por receber recursos de origem estatal, o $\mathrm{STF}^{44}$ pontificou:

“(...) 3. O dever de prestar contas, no caso, não é da entidade, mas da pessoa física responsável por bens e valores públicos, seja ele agente público ou não. 4. Embora a entidade seja de direito privado, sujeita-se à fiscalização do Estado, pois recebe recursos de origem estatal, e seus dirigentes hão de prestar contas dos valores recebidos, quem gere dinheiro público ou administra bens ou interesses da comunidade deve contas o órgão competente para a fiscalização. 5. Hipótese de competência do Tribunal de Contas da União para julgar a matéria em causa, a teor do art. 71, II da Constituição, havendo apuração dos fatos em procedimentos de fiscalização, assegurada ao impetrante ampla defesa (...)

Possui, assim, o Tribunal de Contas a tarefa de controlar se há abusividade ou não nos aumentos de tarifas públicas cobradas para a utilização de um serviço público delegado. O CADE não pode se envolver nesta relação, por não ser afeto à sua competência constitucional este controle contratual público."

Revelando o acerto deste posicionamento, o $\S 1^{\circ}$, do art. $71 \mathrm{da} \mathrm{CF}$, é claro em elencar ao Congresso Nacional, com o preliminar e prévio auxílio do Tribunal de Contas, a sustação de contrato administrativo que possua a pecha de ilegalidade:

“Art. 71 - O Controle externo, a cargo do Congresso Nacional, será exercido com o auxílio do Tribunal de Contas da União, ao qual compete.

43 Cf. Antônio Roque Citadini, O Controle Externo da Administraçāo Pública, 1995, ed. Max Limonad, p. 16.

44 STF, Rel. Min. Néri da Silveira, MS nº 21.644, Pleno, in RDA 207:265. 
$\S 1^{\circ}$ - No caso de contrato, o ato de sustação será adotado diretamente pelo Congresso Nacional, que solitará, de imediato, ao Poder Executivo as medidas cabíveis."

Não resta dúvida que a Constituição de 1988 alargou o campo de atuação das Cortes de Contas, que ao auxiliarem o Poder Legislativo na Fiscalização Contábil, financeira, orçamentária, operacional e patrimonial dos entes públicos, e das entidades da administração direta e indireta, quando à legalidade, legitimidade, economicidade, aplicação das subvenções e renúncia de receitas, materializam o seu munus legal:

“(...) - Com a superveniência da Nova Constituição, ampliou-se, de modo extremamente significativo, a esfera de competência dos Tribunais de Contas, os quais, distanciados do modelo inicial consagrado na Constituição Republicana de 1891 , foram investidos de poderes mais amplos, que ensejam, agora, a fiscalização contábil, financeira, orçamentária, operacional e patrimonial das despesas estatais e das entidades e órgãos de sua administração direta e indireta (...)." 45

O Professor Ricardo Lobo Torres ${ }^{46}$ atento à inovação constitucional, realça o surgimento da novidade, que é o controle do Tribunal de Contas sobre a legalidade, economicidade e legitimidade:

"No texto de 1988 surge a novidade do controle da 'legalidade, economicidade e legitimidade'. As Constituições anteriores se referiam, apenas inicialmente, ao controle da legalidade. Agora o Tribunal de Contas estende a sua ação também à economicidade e legitimidade."

Reforçada a competência do Tribunal de Constas, as suas decisões de que resulte imputação de débito ou multa terão eficácia de título executivo, fazendo coisa julgada material no âmbito administrativo.

Assim sendo, não existe espaço para o CADE se envolver no controle de contas dos entes públicos, aferindo se é ou não lícito determinado reajuste de tarifa de transporte público majorado pelo poder concedente.

A aplicação da Lei $n^{\circ} 8.884 / 94$, aos entes públicos (art. 15) não confere ao CADE o poder de invadir o controle dos aumentos das tarifas públicos, eis que afeta ao controle da Corte de Contas. Agrega-se a este fato que o reajuste da tarifa não materializa abuso do poder econômico que caracteriza a dominação dos mercados, com o extermínio da concorrência.

45 STF, Rel. Min. Celso de Mello, MS21466/DF, Pleno, $D J$ de 6.05.94, p. 10.486.

46 Ricardo Lobo Torres, "A Legitimidade Democrática e o Tribunal de Constas", in RDA 194:32. 
Ademais, as normas gerais sobre contratos administrativos e licitações pertinentes a obras, serviços, inclusive de publicidade, compras, alienações e locações no âmbito dos Poderes da União, dos Estados, do Distrito Federal e dos Municípios, são estabelecidas pela Lei $n^{\circ} 8.666 / 93$.

Já os contratos de concessão e permissão da prestação de serviços públicos previstos no art. 175, da Constituição Federal possuem como peça matriz os dispositivos constantes na Lei ${ }^{\circ} 8.987 / 95$, sendo utilizado, supletivamente, desde que não haja conflito, os dispositivos da Lei $n^{\circ} 8.666 / 93$.

Não resta dúvida de que os princípios (normas gerais) dos aludidos comandos legais deverão ser seguidos à risca por todos os poderes, quando a matéria ventilada for inerente à contratação pública e ao processo licitatório em geral.

E segundo Paulo Bonavides, ${ }^{47}$ os princípios:

“... são ordenações que se irradiam e imantam os sistemas de normas."

Assim, os princípios de uma ciência são os verdadeiros setores, ponto de partida para a compreensão da conduta a ser utilizada pela administração e acatada pelos administrados, irradiando seus efeitos em todas as ordenações existentes, traçando normas do poder a ser exercido pelo gestor público. ${ }^{48}$

Com essa retórica, se tem em sentido puramente técnico, que os princípios do contrato administrativo e da licitação pública são proposições básicas e fundamentais que norteiam as regras que deverão ser seguidas pela Administração pública, guiadas pela Lei no 8.666/93 e pela Lei de Concessões, âncora dos atos e comportamentos que serão adotados para as diversas hipóteses legais ali delineadas.

Para tanto, Celso Antônio Bandeira de Mello ${ }^{49}$ adverte:

"Violar um princípio é muito mais grave que transgredir uma norma qualquer. A desatenção ao princípio implica ofensa não apenas a um mandato obrigatório mas a todo o sistema de comandos. É a mais grave forma de ilegalidade ou inconstitucionalidade, conforme o escalão do princípio atingido, porque representa insurgência contra todo o sistema, subversão de seus valores fundamentais, contumélia irreversível a seu arcabouço lógico de sua estrutura mestra."

O Estado Democrático de Direito, segundo lição de Canotilho ${ }^{50}$ possui como significação a idéia de uma ordem de paz garantida através da ordem constitucional.

47 Paulo Bonavides, Curso de Direito Constitucional Positivo, $9^{\mathrm{a}}$ ed., ed. Malheiros, 1993, p. 84.

48 Licitação e seus Princípios na Jurisprudência, 1999, ed. Lumen Juris, p. 7.

49 Celso Antônio Bandeira de Mello, "Curso de Direito Administrativo", 8 ed., 1996, Malheiros, pág. 546.

50 J.J, Gomes Canotilho, “Direito Constitucional”. 1993, Almedina, Coimbra, pág. 345. 
Especificamente sobre as "Normas Gerais" sobre licitações e contratos administrativos, Renato Geraldo Mendes, ${ }^{51}$ com precisão cirúrgica, enisina:

\begin{abstract}
“A expressão 'normas gerais', é o rótulo ou denominação técnico-jurídica que identifica num conjunto de preceitos de competência constitucional, que devem ser observados pela própria União, Estados, Distrito Federal e Municípios, cujos conteúdos enunciam prescrições uniformizadoras para os referidos entes políticos. As normas gerais são comandos-diretrizes de âmbito nacional."
\end{abstract}

Para Diogo de Figueiredo Moreira Neto, ${ }^{52}$ normas gerais são:

“... Declarações principiológicas que cabe à União editar, no uso de sua competência concorrente limitada, restrita ao estabelecimento de diretrizes nacionais sobre certos assuntos, que deverão ser respeitados pelos estadosmembros na feitura de suas respectivas legislações, através de normas específicas e particularizantes que as detalharão, de modo que possam ser aplicadas, direta e imediatamente, a relações e situações concretas a que se destinam em seus respectivos âmbitos políticos."

Após o presente registro, onde ficou claro que as normas gerais que regem a contratação pública e o processo licitatório são as elencadas nas Leis já declinadas, nunca é demais ressaltar que, em conformidade com a CF e o art. 113 da Lei $n^{\circ}$ 8.666/93, é outorgado ao Tribunal de Contas em todas as esferas do Poder público, Federal, Estadual e Municipal, a competência fiscalizadora sobre as matérias suboculis:

"Art. 113 - O controle das despesas dos contratos e demais instrumentos regidos por esta Lei será feito pelo Tribunal de Contas competente, na forma da legislação pertinente, ficando os órgãos interessados da administração responsáveis pela demonstração da legalidade e regularidade da despesa e execução, nos termos da Constituição e sem prejuízo do sistema de controle interno nela previsto."

Insere-se, neste contexto, os editais de licitação pública, que também sofrem o controle de mérito pelos Tribunais de Contas competentes, a teor do estipulado pelo $\S 2^{\circ}$ do art. 113 , da Lei $n^{\circ} 8.666 / 93$.

$\mathrm{Na}$ trilha da competência legal, cabe ao Tribunal de Contas o controle externo da legalidade do contrato administrativo, bem como das cláusulas dos editais das licitações públicas, sendo defeso ao CADE a apreciação dessas matérias.

51 Renato Geraldo Mendes, "Lei de Licitações e Contratos Anotasa”, $3^{2}$ ed., editora ZNT, 1998, pág. 29

52 Diogo de Figueiredo Moreira Neto, "Competência Concorrente Limitada", apud "Lei de Licitações e Contratos Anotada”, Renato Geraldo Mendes, Cit. ant., pág. 29. 
O CADE, no exercício de sua função, não possui poderes para cancelar ou revogar cláusulas de editais de licitação pública, cabendo-lhe apenas, caso se configure uma conduta anticoncorrencial, oficiar aos órgãos competentes, com a recomendação de que seja adotado determinado procedimento sanatório, ou na hipótese de consumação e irreversibilidade da pseudo-ilegalidade, que ela não conste mais nos futuros editais.

Repita-se, nos casos de contratação e licitação pública, o CADE não possui poder coativo, restringindo-se, apenas à função de opinar, sem impor sanções, em face da competência do Tribunal de Contas sobre a legalidade de tais atos jurídicos. 